\title{
Preliminary Study on Genotoxicity Assessment of an Innovative Topical Treatment for Periodontal Disease
}

\author{
CORINA MARILENA CRISTACHE ${ }^{1,2}$, EUGENIA EFTIMIE TOTU ${ }^{3 *}$, MIHAI BURLIBASA ${ }^{1}$, \\ GABRIELA TANASE ${ }^{4}$, GABRIELA IORGULESCU ${ }^{4}$, LILIANA BURLIBASA $^{5}$ \\ ${ }^{1}$ Carol Davila University of Medicine and Pharmacy, Faculty of Midwifery and Medical Assisting (FMAM), Department of \\ Dental Techniques, 8 Eroilor Sanitari Blvd., 050474, Bucharest, Romania \\ ${ }^{2}$ Concordia Dent Clinic, 7D-7E Vitan-Barzesti Str., Bucharest, Romania \\ ${ }^{3}$ University Politehnica of Bucharest, Faculty of Applied Chemistry and Material Science, 1-5 Polizu Str., 11061 Bucharest, \\ Romania \\ ${ }^{4}$ Carol Davila University of Medicine and Pharmacy, Faculty of Dental Medicine, 19 Plevnei Str., Bucharest, Romania. \\ ${ }^{6}$ University of Bucharest, Faculty of Biology, 91-95 Splaiul Independentei, 050095, Bucharest, Romania
}

\begin{abstract}
The aim of the present study was to assess the genotoxicity of three different antibacterial, antioxidant and antiinflammatory mixtures: tetracycline (T) with metronidazole (MZ), melatonin (MEL) with hyaluronic acid (HA), and $T+M Z+M E L+H A$, in order to choose the best formulation to be used as topic treatment for periodontal disease. In vitro Micronucleus Test was performed (MTvit) according to Organization for Economic Cooperation and Development (OECD) 487 recommendations, in a blind mode, without knowing the composition of the powders evaluated. The highest cytotoxicity and incidence of $M N$ was observed in $T+M Z$ mixture and the mixed compounds $T+M Z+M E L+H A, 1 \mathrm{mg} / \mathrm{mL}$ in the cell culture, registered the lowest incidence of micronuclei, meaning the lowest cytotoxicity, comparable to the negative control sample. Based on the present findings and previously published results, it can be concluded that the complex mixture $T, M Z, M E L$ and HA showed excellent cytotoxicity profiles, with lower rate of chromosomal damage risk, and therefore, is recommended for safe use as topical treatment in periodontal disease.
\end{abstract}

Keywords: cytotoxicity, melatonin, hyaluronic acid, tetracycline, metronidazole, periodontal disease

Periodontal disease is an inflammatory condition with a complex microbial etiology, affecting the supporting structures of the tooth and, if left untreated, may lead to tooth loss. This destructive inflammatory process is influenced by a number of general predisposing factors of exogenous origin as well as functional factors, and is mainly caused by an inadequate interaction between the oral microflora and the host defense mechanisms [1].

Described by either a slow or aggressive evolution, and morphologically characterized by the damage of the dentalperiodontal supporting elements, the occurrence of periodontal pockets and dental mobility, periodontal disease has destructive effect on gingiva and dental-periodontal support, developed through inflammatory processes induced by the microbial biofilm [2]. Inflammation is not only limited to periodontal tissues, bacteria and inflammatory mediators can enter the bloodstream and disseminate systemically, having a significant impact on the general health [3].

Periodontal disease is the leading cause of tooth loss globally, the affected people having an increased risk of losing a large number of masticatory units, with the installation of large / complete edentulous areas and, consequently, masticatory dysfunctions, nutrition impairment and generally, quality of life alteration $[4,5]$.

The treatment of periodontal disease is complex and is addresses to: the reduction of the conditions of development and virulence of the bacterial complex from the dental plaque and periodontal pocket, using local and generally antimicrobial products, antiseptics, antibiotics and oral hygiene products, sustaining the patient's defense mechanisms through the administration of a trophic medication and of various drugs with immunomodulatory effect and, last but not least, to the treatment of systemic diseases influencing the immune response, in which case the interdisciplinary consultation and the collaboration with specialists are called [6].

Modern treatment of periodontal disease begins with bacterial biofilm removal by scaling and root planing (SRP), followed by adjuvant drug therapy targeting infection and inflammation control.

The locally and / or systemically administered periodontal drug treatment uses either anti-infectious factors or immunomodulatory agents that enhance the host's immune response. Topical treatment is recommended as the first therapeutic option to increase efficiency and lower the occurrence of complications [7].

*email: eugenia_totu@yahoo.com All authors have equally contributed to the manuscript, and they should be regarded as main authors. 
TM (Tetracycline \& Metronidazole) paste, a contribution of the modern School of Periodontology in Bucharest [8], recommended, as adjunctive topic treatment, has the following composition: Tetracycline (3g) and Metronidazole (3g) mixed with white Vaseline (100g). TM paste is a topical antimicrobial treatment applied with good results, being known that Tetracycline group drugs are also considered having modulatory effects on the host, by inhibiting the activity of collagenase in the gingival tissue of patients with chronic periodontitis $[9,10]$. Metronidazole is indicated in generalized periodontitis with positive detection for Porphyromonas gingivalis, Bacteroides forsythus, Treponema denticola, Prevotella intermedia, Peptostreptococcus micros, Fusobacterium nucleatum. The local application of tetracycline fibers in patients with chronic periodontitis with probing depth (PD)> 5 showed a significant pockets reduction by $0.7 \mathrm{~mm}$ compared to the control group (SRP only) [11].

The third component, vaseline (petroleum jelly/ petrolatum/ white petrolatum/ soft paraffin) is a semi-solid hydrocarbon $\mathrm{C}_{15} \mathrm{H}_{15} \mathrm{~N}$ (1,1,2-Trimethylbenzeindole) promoted as a topical ointment for its healing properties [12], is used as vehicle.

Recently, melatonin and hyaluronic acid alone and associated with antimicrobial agents were also proposed for their anti-inflammatory and antioxidant effect for topic application to improve local treatment in periodontal disease [10-14].

The aim of the present study was to assess the genotoxicity of three different antibacterial, antioxidant and antiinflammatory mixtures in order to choose the best formulation to be used as topic treatment for periodontal disease.

\section{Experimental part}

The necessary chemicals: N-acetyl-5-methoxytryptamine - melatonin (MEL), tetracycline (T), hyaluronic acid (HA), and metronidazole (MZ) were purchased from Sigma-Aldrich (Merck KGaA GmbH, Germany). All compounds are powders, MEL and HA are white crystalline powders; T is available as yellow crystalline powder and M, as white to paleyellow crystalline powder. The following mixtures of powders have been prepared: Mixture 1 (M1) - $3 \mathrm{~g} \mathrm{~T}$ and $3 \mathrm{~g}$ MZ (yellow color powder); Mixture 2 (M2) - 0.18g MEL and 3g HA (white color powder); and Mixture 3 (M3) - 3g T, 3g $\mathrm{MZ}, 0.18 \mathrm{~g}$ MEL and 3g HA (yellow color powder). The mixtures were purred in dark color recipients and blinded prior to sending for genotoxicity assessment.

In vitro micronucleus (MNvit) test was conducted in compliance with Organization for Economic Cooperation and Development (OECD) 487 recommendations. Human lymphocyte cultures were initiated. Peripheral blood was taken from a middle-aged, healthy male who had not been recently exposed to genotoxic agents (chemical substances, ionizing radiations, bacterial/viral infections). Peripheral blood was collected using heparin based anticoagulant. About $0.5 \mathrm{~mL}$ of heparinized blood was transferred in a tube containing $10 \mathrm{~mL}$ supplemented GIBCO PB-MAX Karyotyping Medium (from Thermo Fisher Scientific). The culture was incubated at $37^{\circ} \mathrm{C}$ for $24 \mathrm{~h}$. Each mixture (M1-M3) was introduced in the human lymphocytes culture $24 \mathrm{~h}$ after the culture was initiated. All samples were previously sterilized by exposing to UV for $15 \mathrm{~min}[15,16]$. Two concentrations for each type of a sample were tested: $1 \mathrm{mg} / \mathrm{mL}$ and $2 \mathrm{mg} / \mathrm{mL}$. A specimen free of chemical was used as control. Each sample was performed in duplicate.

The cultures were sacrificed $72 \mathrm{~h}$ after tested mixture was added, which was enough time for the cells to undergo several cell division rounds so that potential DNA damage in the form of micronuclei in interphase cells could be identified. The culture was developed without adding cytochalasin B (cytoB) actine polymerisation inhibitor. In the next steps the cultures were sacrificed by hypotonization using potassium citrate solution (Merck KGaA GmbH, Germany), and cells were fixed in 3:1 methanol/acetic acid solution (Merck KGaA GmbH, Germany). Microscope slides were prepared, stained using Giemsa solution (Sigma-Aldrich from Merck KGaA GmbH, Germany), after being previously treated with Trypsin - Ethylene-diamine-tetra acetic acid (EDTA) (Sigma-Aldrich (Merck KGaA GmbH, Germany). An Olympus BX40 microscope was used to analyze the slides.

\section{Results and discussions}

In order to preliminary analyze the genotoxic of the three mixtures (M1-M3) in vitro Micronucleus Test was performed (MTvit) according to the procedure described in Experimental paragraph, in a blind mode, without knowing the composition of the powders evaluated. The human lymphocyte micronucleus test is an established method used both in epidemiological investigations and in the in vitro micronucleus test [17]. Human lymphocytes have the advantage that they are primary human cells which are relatively easy to culture in suspension [18]. Due to the fact that the cultures were performed without cytoB, Relative Increase in Cell Count (RICC) index was used to demonstrate that the cells scored in the culture have undergone division during or following treatment with the test substance, otherwise false negative responses may be recorded [19].

Cytotoxicity was calculated using the following formula:

$$
\text { Cytotoxicity }=100-\text { RICC, were }
$$




$$
\text { RICC }=\frac{(\text { Increase in number of cells in treated cultures }(\text { final }- \text { starting }))}{(\text { Increase in number of cells in control cultures }(\text { final }- \text { starting }))} \times 100
$$

The results are presented in Table 1 .

Table 1

CYTOTOXICITY MEASURED BASED ON RICC, EVALUATING THE INCREASE IN THE NUMBER OF CELLS IN CHEMICALLY-EXPOSED CULTURES VERSUS INCREASE IN NON-TREATED CULTURES, FOR THE THREE POWDER MIXTURES IN TWO CONCENTRATIONS OF THE SAMPLES IN THE CELL CULTURE, EXPRESSED AS A PERCENTAGE

\begin{tabular}{|c|c|c|}
\hline $\begin{array}{c}\text { Type of powder } \\
\text { mixture }\end{array}$ & \multicolumn{2}{|c|}{ Cytotoxicity depending on the concentration of the sample in the cell culture } \\
\cline { 2 - 3 } & $\mathbf{1 ~ \mathbf { ~ g } / \mathbf { m L }}$ & $\mathbf{2 ~ \mathbf { ~ g } / \mathbf { m L }}$ \\
\hline $\mathrm{T}+\mathrm{MZ}$ & $42.2 \%$ & $59.2 \%$ \\
\hline MEL+HA & $40.4 \%$ & $56.7 \%$ \\
\hline $\mathrm{T}+\mathrm{MZ}+\mathrm{MEL}+\mathrm{HA}$ & $39.1 \%$ & $42.3 \%$ \\
\hline
\end{tabular}

The cytotoxicity was calculated based on the RICC index for the two concentrations. As shown in Table 1, a correct evaluation can be made, without false positive results. If the cytotoxicity exceeds $60 \%$ ( $40 \%$ cell viability), it determines the occurrence of the micronuclei $(\mathrm{MN})$, as a side effect of the cytotoxicity; consequently, the incidence of $\mathrm{MN}$ due to the genotoxic capacity of the tested product cannot be evaluated.

The MN incidence analysis depending on the concertation of the samples is presented in Table 2.

Table 2

THE INCIDENCE OF MN ANALYSIS FOR TWO CONCENTRATIONS OF THE SAMPLES AND THE NEGATIVE CONTROL

\begin{tabular}{|c|c|c|}
\hline \multirow{2}{*}{$\begin{array}{l}\text { Type of tested } \\
\text { sample }\end{array}$} & \multicolumn{2}{|c|}{ The concentration of the sample in the cell culture } \\
\hline & $1 \mathrm{mg} / \mathrm{mL}$ & $2 \mathrm{mg} / \mathrm{mL}$ \\
\hline $\mathrm{T}+\mathrm{MZ}$ & $10.5 \%$ & $20.0 \%$ \\
\hline MEL+HA & $7.5 \%$ & $8.0 \%$ \\
\hline $\mathrm{T}+\mathrm{MZ}+\mathrm{MEL}+\mathrm{HA}$ & $5.0 \%$ & $8.5 \%$ \\
\hline Negative control & \multicolumn{2}{|c|}{$4.0 \%$} \\
\hline
\end{tabular}

According to OEDC, the MNvit assay (487 OEDC Guideline) [19] is recommended as basic test to assess and characterize the genotoxic capacity of chemical/ pharmaceutical agents. It is used to detect the micronuclei in the cytoplasm of interphase cells. Micronuclei area centric (without centromere), chromosomal fragments or whole chromosomes unable to migrate to one of the two poles of the cell during anaphase through in vitro micronucleus test, the frequency of chromosomal damage as well as of the disturbance in the cell cycle progression caused by a chemical agent (which is tested), can be rapidly determined. Measurements of cell proliferation are made to assure that the treated cells have undergone mitosis during the assay and that the treatments are conducted at appropriate levels of cytotoxicity. In studies without cytoB, it is necessary to demonstrate that the cells scored in the culture have undergone division during or following treatment with the test substance, otherwise false negative responses may be produced, therefore RICC index was used. MNvit test has become more popular than the chromosomal aberrations test (CAAT) because it is more feasible, easy to conduct, rapid, and more sensitive in detecting subtle damage caused by aneugenic and clastogenic agents [19].

After revealing the composition of each powder, it can be observed, from Table 2 and Figure 1, that the mixed compound $\mathrm{T}+\mathrm{MZ}+\mathrm{MEL}+\mathrm{HA}, 1 \mathrm{mg} / \mathrm{mL}$ in the cell culture, registered the lowest incidence of micronuclei, comparable to the negative control sample. 

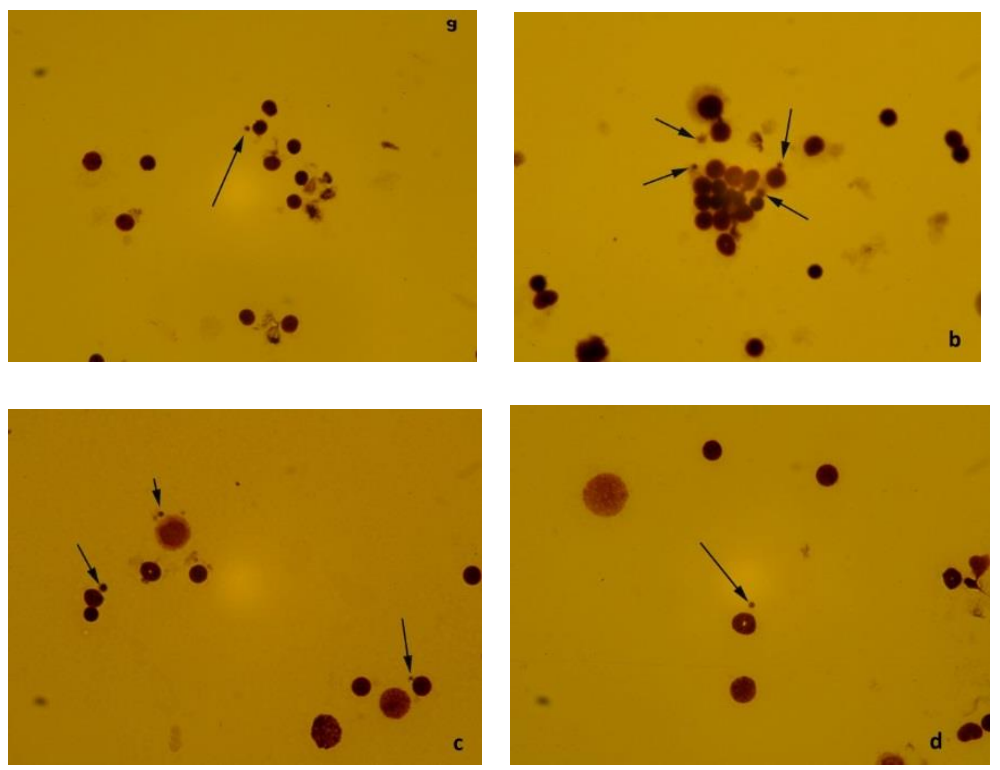

Fig. 1 MNvit analysis: normal metaphase with nuclei and micronucleus (arrow) from negative control (a); micronucleus (arrow) from $\mathrm{T}+\mathrm{MZ}$ (b); micronucleus (arrow) from MEL+HA (c); and micronucleus (arrow) from $\mathrm{T}+\mathrm{MZ}+\mathrm{MEL}+\mathrm{HA}(\mathrm{d})$.

The highest cytotoxicity and incidence of $\mathrm{MN}$ was observed in $\mathrm{T}+\mathrm{MZ}$ mixture. However, both of the concentration used favors the assessment of the genotoxic capacity.

Despite of the fact that $\mathrm{T}$ is one of the most popular antibiotics for treating anaerobic bacterial infections, recent study showed that $\mathrm{T}$ have some side effects on mammalian cells such as inhibition of certain proteins and cell proliferation by binding to 30S ribosomal subunits [20]. It could alter the integrity of cell membranes, resulting in macromolecular dysfunction, cellular lysis and cell mortality [21]. $\mathrm{T}$ is also a significant inhibitor of mammalian mitochondrial protein synthesis, which will lead to interference with growth, oxygen consumption and fertility [22].

MZ antibacterial mechanism follows four steps: first, it enters susceptible organisms (anaerobic or microaerophilic microorganisms and hypoxic or anoxic cells); next, the nitro group of MZ is reduced by electron transport proteins and deprives the cell of required reduction mechanisms; following this reductive activation step, the reduced intermediate molecule binds to microbial deoxyribonucleic acid (DNA), causing loss of helical structure, strand breakage, and impairment of normal DNA function. Cell death is caused by this disruption and degradation of the cellular DNA and by the release of inactive and nonfunctional cellular end products [23]. MZ is well tolerated with mild to moderate side effects on mammalian cells. Serious neurotoxicity, optic neuropathy, peripheral neuropathy, and encephalopathy have been reported in rare cases, probably due to free radicals damage nerves, or a formation of a thiamine analog derived from MZ that may result in a nutrition deficiency-like neuropathy [24]. However, as could be observed from Table 2, MNvit test scored $10.5 \%$ for $1 \mathrm{mg} / \mathrm{mL}$ and almost double $(20.0 \%$ ) for $2 \mathrm{mg} / \mathrm{mL}$.

In order to promote periodontal repair after SRP - conservative therapy including the surgical debridement of the periodontal pathogenic microorganisms, mineralized deposits on the root surface, infected cementum as well as all the injured/necrotic tissue parts [25], adjunctive anti-inflammatory therapy is recommended.

Recently, we have proposed a mixture of MEL and HA based on their complementary effects, with the preservation of the identity and characteristic properties of each component, as determined via first derivative UV-Vis spectrophotometry [26], FT-IR analysis [14] and fluorescence microscopy [13].

The rationale for proposing the complex mixture M3 for topical use as adjunctive treatment in periodontal disease Fig. 2, was based on the individual properties of each component, as presented in Table 3.

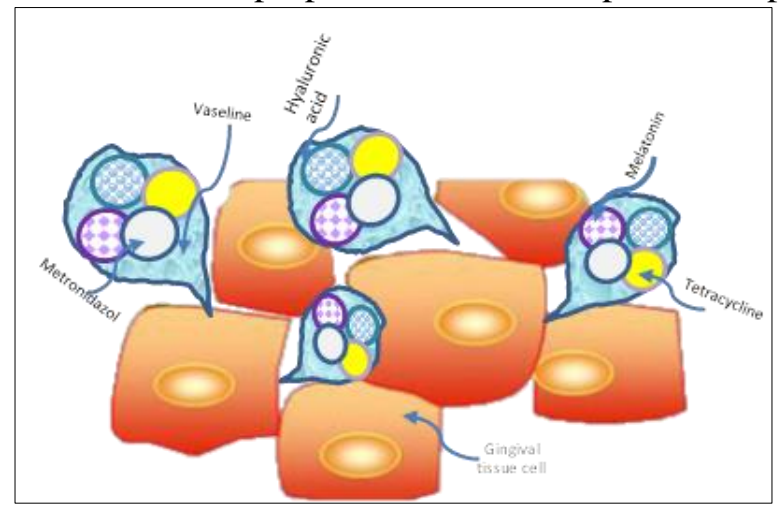


Table 3

COMPONENTS OF THE PROPOSED MIXTURE FOR TOPICAL TREATMENT IN PERIODONTAL DISEASE

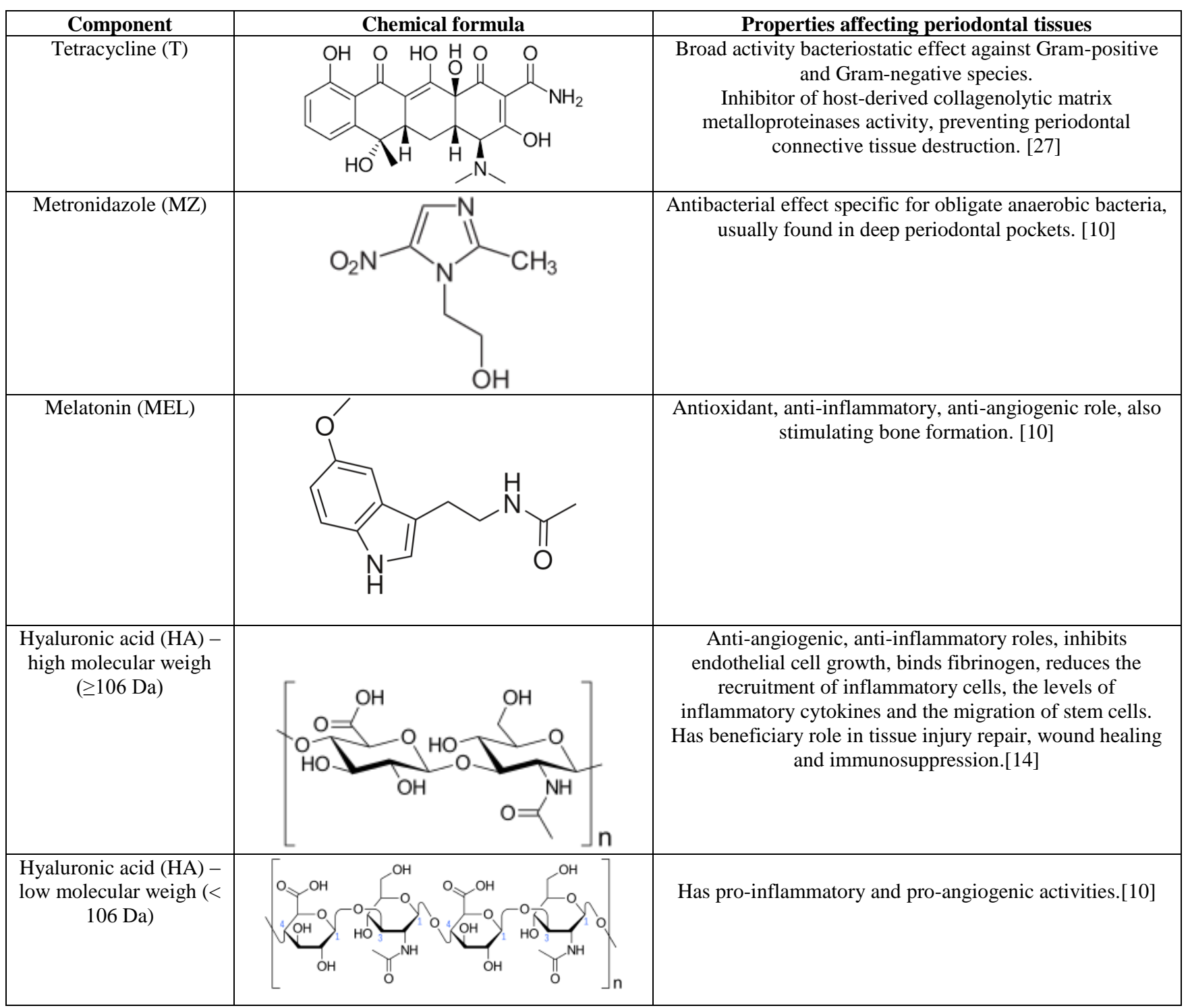

As it can be observed from Table 2, by adding MEL and HA to the power mixture $\mathrm{T}+\mathrm{MZ}$, the incidence of MN significantly drops to $5.0 \%$ o for $1 \mathrm{mg} / \mathrm{mL}$ being close to the negative control sample $(4.0 \%)$. This highly decrease in genotoxicity is probably due to the fact that MEL can reduce the toxicity by being a potent free radical scavenger.

MEL was proved to detoxify numerous reactive oxygen species (ROS) - Fig.3, including hydrogen peroxide $\left(\mathrm{H}_{2} \mathrm{O}_{2}\right)$, hydroxyl radical $(\mathrm{OH} \cdot)$, peroxyl radicals $\left(\mathrm{HO}_{2} \cdot \mathrm{ROO} \cdot\right)$ and singlet oxygen $\left({ }^{1} \mathrm{O}_{2}\right)$, and also reactive nitrogen species (RNS) such as nitric oxide radical (NO•) and peroxy-nitrite $\left(\mathrm{ONOO}^{-}\right)$[28]. The core structure for MEL requiring scavenging free radicals is the indole heterocycle. The electron-rich indole moiety with high resonance stability and electro reactivity determines MEL's potent free radical scavenging capacity [29].

$$
\begin{gathered}
\mathrm{O}_{2}+\mathrm{e}^{-} \rightarrow \mathrm{O}_{2}{ }^{--} \\
\mathrm{O}_{2}{ }^{-}+2 \mathrm{H}^{+}+2 \mathrm{e}^{-} \rightarrow \mathrm{H}_{2} \mathrm{O}_{2} \\
\mathrm{O}_{2}{ }^{--}+\mathrm{H}_{2} \mathrm{O}_{2} \rightarrow \\
\mathrm{O}_{2}+\mathrm{HO}^{-}+\mathrm{HO}^{-} \text {(Heber-Weiss reaction) } \\
\mathrm{HO}+\mathrm{R}-\mathrm{H} \rightarrow \mathrm{H}_{2} \mathrm{O}+\mathrm{R}^{\cdot} \\
\mathrm{HO}^{-}+\mathrm{H}^{+}+\mathrm{e}^{-} \rightarrow \mathrm{H}_{2} \mathrm{O}+v \text { (Photon) }
\end{gathered}
$$

Fig. 3. Formation of reactive oxygen species [30] 
The association between T, MZ, MEL and HA (M3), as described in the Experimental paragraph, was proved to induced the lower rate of chromosomal damage $(5.0 \%$ for $1 \mathrm{mg} / \mathrm{mL})$, even lower than MEL and HA alone (M2), $7.5 \%$ for $1 \mathrm{mg} / \mathrm{mL}$ (Table 2), and the lowest cytotoxicity rate as well (Table 1).

\section{Conclusions}

Based on the present findings and previous published results, it can be concluded that the complex mixture T, MZ, MEL and HA showed excellent cytotoxicity profiles, with lower rate of chromosomal damage risk and therefore is recommended for safe use as topical treatment in periodontal disease.

Acknowledgments: This work was supported by a grant of the Romanian National Authority for Scientific Research and Innovation, CCCDI UEFISCDI, project number 39/2018 COFUND-MANUNET III-HAMELDENT, within PNCDI III.

\section{References}

1.LANG, N.P., LINDHE, J., Clinical Periodontology and Implant Dentistry, John Wiley \& Sons, 6th Edition, Chichester, 2015.

2.LOE, H., Int Dent J, 50, no.3, 2000, p129.

3.SAFFI, M. A., FURTADO, M.V., MONTENEGRO, M. M., RIBEIRO, I.W., KAMPITS, C., RABELO-SILVA, E. R., POLANCZYK, C. A., ROSING, C. K., HAAS, A. N.. Trials, 14, no.283, 2013.

4.TONETTI, M. S., JEPSEN, S., JIN, L., OTOMO-CORGEL, J., J Clin Periodontol, 44, no.5, 2017, p.456.

5.AL-HARTHI, L. S., CULLINAN, M. P., LEICHTER, J. W., THOMSON, W. M., Aust Dent J, 58, no.3, 2013 , p.274.

6.NEEDLEMAN, I., The Good Practitioner's Guide to Periodontology. Br Soc Periodontol 2016.

7.ECHEVERRIA, J. J., ECHEVERRIA, A., CAFFESSE, R. G., Periodontol 2000, 79, no.1, 2019, p.200.

8.DUMITRIU, H., DUMITRIU, S., DUMITRIU, A.S., Parodontologie, Editia a IV-a, Ed Viata Medicala Romaneasca, Bucuresti, 2006.

9.FERES, M., FIGUEIREDO, L. C., SOARES, G. M., FAVERI, M., Periodontol 2000, 67, no.1, 2015, p.131.

10.CRISTACHE CM, TOTU EE, TANASE G, NECHIFOR AC, PETRE D, BURLIBASA M., Rev.Chim., 70, no.7, 2019 , p.2485.

11.MATESANZ-PEREZ, P., GARCIA-GARGALlO, M., FIGUERO, E., BASCONES-MARTINEZ, A., SANZ, M., HERRERA, D., J Clin Periodontol, 40, no.3, 2013, p.227.

12.*** https://www.chemicalbook.com/ProductChemicalPropertiesCB9854422_EN.htm

13.TOTU, E. E., CRISTACHE, C. M., BUGA, R., DUMITRU, F., TOTU, T., Rev.Chim., 70, no.5, 2019, p.1551.

14.CRISTACHE, C. M., TOTU, E. E., CRISTACHE, G., NECHIFOR, A. C., PINTILIE, I. I., Rev.Chim., 70, no.3, 2019 , p.1089.

15.BURLIBASA, M., CRISTACHE, C. M., GEORGESCU, S. R., DUMITRIU, A. S., NEAMTU, R., NITESCU, M., Metal Int, 14, 2009 , p.20.

16.TOTU, E. E., CRISTACHE, C. M., ISILDAK, I., YILDIRIM, R., BURLIBASA, M., NIGDE, M., BURLIBASA, L. Rev Chim., 69, no.5, 2018, p.1160.

17.KIRSCH-VOLDERS, M., DECORDIER, I., ELHAJOUJI, A., PLAS, G., AARDEMA, M. J., FENECH, M., Mutagenesis, 26, no.1,2011, p.177. 18.LOVELL, D. P, FELlOW, M., ELHAJOUJI, A., FARABAUGH, C. S., GILBY, B. G., HASHIMOTO, K., LI, Y., ROY, S., SCHULER, M., WHITWELL, J., TANIR, J. Y., Mutat Res - Genet Toxicol Environ Mutagen, 837, no.52, 2019.

19.*** OECD Guidelines for the Testing of Chemicals, Test no 487, Section 4, OECD Publishing, Paris, 2012.

20.BRODERSEN, D. E., CLEMONS, W. M., CARTER, A. P., MORGAN-WARREN, R. J., WIMBERLY, B. T., RAMAKRISHNAN, V., Cell, 103, no.7, 2000, p.1143.

21.MCKEE, E. E., FERGUSON, M., BENTLEY, A. T., MARKS, T. A., Antimicrob Agents Chemother, 50, no.6, 2006, p.2042.

22.CHATZISPYROU, I. A., HELD, N. M., MOUCHIROUD, L., AUWERX, J., HOUTKOOPER, R. H., Cancer Res, 75, no.21, 2015 , p.4446.

23.FITZGERALD, K. T., Metronidazole, Small Anim Toxicol (Third Edition), 2013, p.653, doi:10.1016/B978-1-4557-0717-1.00061-2.

24.HERNANDEZ CERUELOS, A., ROMERO-QUEZADA, L. C., RUVALCABA LEDEZMA, J. C., LOPEZ CONTRERAS, L., Eur Rev Med Pharmacol Sci, 23, no.1, 2019, p.397.

25.IVIGLIA, G., KARGOZAR, S., BAINO, F., J Funct Biomater, 10, no.1, 2019. doi:10.3390/jfb10010003.

26.CRISTACHE, C., M., TOTU, E., E., PETRE, D., BUGA, R., CRISTACHE, G., TOTU, T., Rev. Chim., 69, no.8, 2018, p.1996

27.GOLUB, L., M., ELBURKI, M., S., WALKER, C., RYAN, M., SORSA, T., TENENBAUM, H., GOLDBERG, M., WOLFF, M., GU, Y. Int Dent J, 66, no. 3, 2016, p.127

28.TAN, D., REITER, R., MANCHESTER, L., YAN, M., EL-SAWI, M., SAINZ, R., MAYO, J. C., KOHEN, R., ALLEGRA, M., HARDELAND, R., Curr Top Med Chem, 2, no.2, 2005, p.181.

29.POEGGELER, B., REITER, R. J., TAN, D. X., CHEN, L. D., MANCHESTER, L. C., J Pineal Res, 14, no.4, 1993 , p.151.

30.PANTEA STOIAN, A., MITROFAN, G., COLCEAG, F., SERAFINCEANU, C., TOTU E. E., MOCANU V., MANUC, D., CARAUSU, E. M., Proceedings, 11, no.1, 2019. doi:10.3390/proceedings2019011007.

$\overline{\text { Manuscript received: } 27.11 .2019}$ 